\title{
Technical and Cultural Perspectives of Charcoal Burning in Nineteenth Century Wisconsin, USA
}

\author{
Thomas J. Straka ${ }^{1 *}$, Lawrence A. Gueller ${ }^{2}$ \\ ${ }^{1}$ Department of Forestry and Environmental Conservation, Clemson University, Clemson, SC, USA \\ ${ }^{2}$ Independent Researcher, Keshena, WI, USA \\ Email: *tstraka@clemson.edu
}

How to cite this paper: Straka, T. J., \& Gueller, L. A. (2021). Technical and Cultural Perspectives of Charcoal Burning in Nineteenth Century Wisconsin, USA. $A d$ vances in Historical Studies, 10, 53-72. https://doi.org/10.4236/ahs.2021.101006

Received: January 12, 2021

Accepted: March 21, 2021

Published: March 24, 2021

Copyright () 2021 by author(s) and ScientificResearch Publishing Inc.

This work is licensed under the CreativeCommons Attribution International

License (CC BY 4.0).

http://creativecommons.org/licenses/by/4.0/

\section{Open Access}

\begin{abstract}
Iron production in the United States was fueled entirely by charcoal until the mid-nineteenth century when coal and coke began to dominate as the preferred fuel. Even so, charcoal iron production increased in absolute terms until 1890 and continued until 1945. The early iron industry could not have existed without the secondary charcoal burning (production) industry. Charcoal burning was an important industry in regions with iron production, provided a market for wood after the clearing of land for agricultural production, and contributed to forest depletion near charcoal iron furnaces. We describe technical and cultural aspect of the charcoal burning industry in Wisconsin, part of a region with significant charcoal iron production. Charcoal was produced in pits and kilns. Our discussion centers on pit production of charcoal. Production methodology via pits is discussed in detail, illustrating production techniques common to both charcoal pits and kilns. Charcoal burning's contribution to forest depletion is part of that discussion.
\end{abstract}

\section{Keywords}

Wisconsin Charcoal Burning, Charcoal Pit, Charcoal Kiln, Wisconsin Charcoal Iron Industry, Collier

\section{Introduction}

Iron production in the United States was fueled entirely by charcoal until the mid-nineteenth century when coal and coke began to dominate as the preferred fuel. Even so, due to vastly increasing iron output after the Civil War, in absolute terms, production of charcoal iron increased until 1890 and continued until 1945 (Schallenberg, 1975; Schallenberg \& Ault, 1977). While iron production was essentially an eastern enterprise in the United States, gold, silver, and lead 
smelters also consumed vast amount of charcoal in the American West (Fell, 2009; Raymond, 1875). Charcoal as a fuel played a huge role in the technological development of the world's manufacturing capacity (Coman, 1918; Swank, 1892). It also had a role in the forest history of regions where wood was harvested to produce charcoal (Ise, 1920).

Charcoal's use as a fuel, its production parameters, and its contribution to forest depletion have been discussed in this journal (Straka, 2014, 2017); however, the actual production process was not included in that discussion. We provide a discussion of the production process in a regional context to highlight interesting distinctive characteristics of Wisconsin charcoal burning (or production) and to illustrate how exactly wood was turned into charcoal. Early charcoal production took place in earth-covered charcoal pits, stone or brick (or both) charcoal kilns, or later, retorts. We will center our discussion on charcoal pits, which best demonstrate the production process. The authors recently reviewed kiln production of charcoal in Wisconsin in a related journal article (Straka \& Gueller, 2020).

\section{The Iron Furnaces, Charcoal Demand, and Wood Scarcity}

Early Wisconsin history, especially in the southwestern part of the state, is well-known for lead mining as a primary industry (Janik, 2010). Lessor known is the pioneer iron industry that also developed in the southern part of the state over the 1850s, mainly in Dodge, Sauk, and Jackson Counties. By the end of that decade Wisconsin boasted three iron furnaces and a small iron smelting industry built to use local ores (Irving, 1883).

The essential fuel for Wisconsin's early iron industry was charcoal. Charcoal burning is a largely forgotten secondary industry in the state. It impacted the state's economy and devastated many hectares of Wisconsin forest land. An expanding iron industry meant an expanding demand for charcoal. Beginning in the early 1870s, anthracite coal and bituminous coke gradually became the dominant fuel, but charcoal iron was produced in Wisconsin until the early twentieth century (Dodd, 1944).

The connection of the iron industry to charcoal and Wisconsin's forests is an interesting one. A tangible product of that connection was the many charcoal kilns constructed across the state, mostly located along the railroad lines, to utilize more and more wood to meet charcoal demand. The charcoal iron industry will be briefly described to define the demand for this charcoal fuel in terms of volume and geography.

The first iron furnace in the state was built in Dodge County at Mayville in 1848 and began operation in 1849. It used charcoal as fuel until 1887 when it was remodeled and enlarged in order to use coke as a fuel. The Sauk County iron furnace was built in 1857 at Ironton to produce both castings and pig iron. The third furnace, erected in 1857 at Black River Falls in Jackson County, was small and soon abandoned due to lean ore (American Iron and Steel Association, 1892). The first reported annual output of pig iron from Wisconsin was 2,268 
metric tons (2500 tons) in 1856 (Lesley, 1857). In 1865 a charcoal furnace was added at Iron Ridge, near Mayville. At the time of the Civil War iron production in Wisconsin was centered at these locations (Merk, 1916).

After the Civil War many charcoal iron furnaces were constructed in the eastern part of the state with access to Lake Michigan, mainly to smelt iron ores from Michigan's Upper Peninsula (Swank, 1892). Eleven new iron furnaces were constructed in Wisconsin between 1869 and 1874: the two Fox River Furnaces at West De Pere in Brown County, built in 1869 and 1872; the two National Furnaces at De Pere in Brown County, built in 1869 and 1870; the Green Bay Furnace in Green Bay, built in 1870; the two Bay View Furnaces in Milwaukee County, built in 1870 and 1871; the Minerva Furnace in Milwaukee, built in 1873; the two Appleton Furnaces, built in 1871 and 1872; and the Fond du Lac Furnace, built in 1874 and first put into blast in 1883 (American Iron and Steel Association, 1890).

A furnace was built at Cazenovia in Richland County (Richland Iron Company) in 1876, but was abandoned three years later. The Florence Furnace in then-Marinette County was built in 1881. Black River Falls in Jackson County was the site of a second charcoal iron furnace erected by the York Iron Company in 1886. Most of the later furnaces used ore from Michigan's Upper Peninsula. All but the three furnaces at Bay View and Milwaukee used charcoal as their fuel. By 1890, seven of these furnaces were abandoned: two at Appleton, two at Fox River, and one each at Green Bay, De Pere, and Iron Ridge (Irving, 1883; Swank, 1892).

An 1882 federal survey of iron furnaces presented an overview of Wisconsin furnaces, using bushels as units of consumption (a bushel is 35.24 liters in volume or about nine kilograms in weight). Average annual charcoal fuel consumption at a furnace was 800,000 bushels with cost averaging for six to seven and one-half cents per bushel. The cost of labor in cutting wood was 60 to 80 cents per cord. A standard cord is a stack of wood which measures 1.22 by 1.22 by 2.44 meters, or 3.62 cubic meters (four by four by eight feet, or 128 cubic feet). The cost of teaming, or hauling, wood or charcoal was $\$ 1.25$ to $\$ 2.50$ per day and a charcoal burner earned from $\$ 1.40$ to $\$ 1.50$ per day. Charcoal pits ranged in cordwood capacity from 25 to 60 cords, with a yield of $331 \frac{1}{2}$ to 43 bushels of charcoal per cord (Hough, 1882). For comparison, kilns had reported capacities of 30 - 45 cords, with a very few kilns having a 100-cord capacity (Straka \& Gueller, 2020). Both pits and kilns were huge, with a mid-range capacity of about 110 to 140 cubic meters of wood ( 4000 to 5000 cubic feet).

In the mid-1880s the vast iron deposits of the Gogebic Range attracted the iron industry to northern Wisconsin on the border of Michigan and Wisconsin and it remained there until the last iron mine closed in Wisconsin in the late-1960s (Current, 1977). In 1887-1888 a large charcoal iron furnace was constructed at Ashland (the Hinkle Furnace) that would prove to be one of the best producers of charcoal iron in the country (Swank, 1892). Iron ore deposits were discovered near Spring Valley in Pierce County about 1890 and a smelter began 
operation in 1894. By 1896 there were two only two charcoal iron furnaces in the state, one at Spring Valley and one at Ashland (American Iron and Steel Association, 1896). In 1899 the Spring Valley furnace converted to coke as fuel, leaving only the Hinkle Furnace in Ashland still using charcoal as its primary fuel (American Iron and Steel Association, 1904). The Ashland Furnace ceased operation in 1925, due to exhaustion of the hardwood forest (Smith \& Goc, 1987).

In 1872 the iron production capacity In Wisconsin was approximately 61,000 metric tons (67,000 tons). One half of this total was produced with a mixture of coke and anthracite coal and one half with charcoal. The Milwaukee Iron Company produced 30,000 metric tons (33,000 tons) using coal and coke. The remaining smelters used charcoal: Northwestern Iron Company (Mayville) 2722 metric tons (3000 tons), Wisconsin Iron Company (Iron Ridge) 3000 metric tons (3300 tons), J. F. Smith (Ironton) 1179 metric tons (1300 tons), National Iron Company (De Pere) 5900 metric tons (6500 tons), Fox River Iron Company (De Pere) 6350 metric tons (7000 tons), Green Bay Iron Company 5443 metric tons (6000 tons), and Appleton Iron Company 5900 metric tons (6500 tons) (Swank, 1873). By 1889 total output increased to 144,000 metric tons $(158,634$ tons) and just over half of it was produced with charcoal fuel (Birkinbine, 1890).

Peak annual capacity for charcoal iron furnaces in Wisconsin by location from 1880-1894 can be determined from the Directory of the Ironand Steel Workers of the United States for those years. It presents a picture of related charcoal demand in the state. Appleton's peak capacity was 13,608 metric tons $(15,000$ tons); Ashland's peak capacity was 40,823 metric tons (45,000 tons); Black River Fall's peak capacity was 22,680 metric tons (25,000 tons); Brown County's peak capacity was 37,195 metric tons (41,000 tons); Dodge County's peak capacity was 13,154 metric tons (14,500 tons); Florence's peak capacity was 5443 metric tons (6000 tons); Fond du Lac's peak capacity was 18,597 metric tons (20,500 tons); Ironton's peak capacity was 3175 metric tons (3500 tons); and Spring Valley's peak capacity was 19,958 metric tons (22,000 tons).

Iron furnaces were the demand for charcoal fuel, so they defined the geography of that demand. Early charcoal iron production in Wisconsin was centered in Dodge County from 1849 to 1887 and Sauk County from 1857 to 1895 . Major charcoal demand, from the early 1870s until the mid-1890s, developed from the eight new charcoal iron furnaces built in the Fox River Basin at De Pere, Green Bay, Appleton, and Fond du Lac. Later charcoal demand areas developed in Black River Falls from 1886 to 1892, in Florence from 1881 to 1895, in Spring Valley from 1894 to 1899, and in Ashland from 1888 to 1925.

When the three furnace companies began operations in Brown County, each required roughly 30,000 cords of wood per season for charcoal production. Each of the two furnaces at West De Pere, on a daily basis, would consume the wood from at least 0.6 hectares (one and one-half acres). When the last furnace in Brown County was abandoned in the early 1890s, the growing scarcity of timber was cited as a primary reason for furnace closures; charcoal had to be brought in by rail from kilns near Escanaba on Michigan's Upper Peninsula, “there being 
scarcely enough wood in Brown County for fire wood for the farmers" (Martin, 1913).

Fire damage stopped production at the Appleton Furnace in 1888 and it did not resume due to cordwood scarcity as Outagamie County had been denuded of its timber and charcoal had to be produced from about 80 kilometers (50 miles) away northwest of Appleton (Ryan, 1911). The Fond du Lac Furnace was ready for operation in 1874, but it was not put into blast until 1883 as a lack of a local wood supply delayed operations. The owner, Charles J. L. Meyer, purchased timberland on Michigan's Upper Peninsula and planned to move the furnace to that location. Local capitalists had to organize to prevent this move by purchasing the furnace (Francis, 1882; Western Historical Company, 1880a). Cordwood scarcity then forced the company to procure wood from well over 161 kilometers (100 miles) distant, from Wood, Marathon, and Clark Counties (Curtiss-Wedge, 1918; Jones \& McVean, 1923; Straka \& Gueller, n.d.).

Even the "older" furnaces further south were subject to cordwood shortages. In 1879 the furnace in Iron Ridge in Dodge County was in desperate need of charcoal due to a lack of cordwood near its furnace, forcing it to locate kilns adjacent to the Milwaukee Lake Shore and Western Railroad, well over 161 kilometers (100 miles) distant (Charcoal Industry, 1879). When the Ironton Furnace was abandoned in the mid-1890s, the price of charcoal would be a major contributing factor to its closing (Walters, 1924; Winn, 1989). When the charcoal source was primarily derived from charcoal pits, such as at Ironton, the furnace was not located necessarily close to the mine; charcoal fuel was so important and cordwood and fuel transportation so expensive, that closeness of cordwood became an important furnace location factor (Western Historical Company, 1880b).

\section{Pit Production of Charcoal in Wisconsin}

While the development of the iron smelting industry is a truly fascinating part of American industrial history, some of the history of its related industries can be equally as fascinating. Iron furnaces were economic centers which required basic raw materials: ore, limestone, and charcoal. Suppling each of the three ingredients meant that a large labor force was necessary, as well as a settlement for the workers. Charcoal production was labor-intensive and accounted for nearly a half of a typical labor force for an iron furnace. Most of the laborers were woodcutters who harvested the wood. Converting this wood into charcoal, called charcoal burning, was an art, requiring a collier with a special set of skills (Straka \& Ramer, 2010). The blue smoke from charcoal burners was a common sight throughout the eighteenth and nineteenth centuries anywhere in America where iron was produced, including the state of Wisconsin.

Charcoal is the solid residue produced when wood is "burned" in a confined space with limited air (oxygen) at a high temperature $\left(300^{\circ} \mathrm{C}\right.$ or $\left.572^{\circ} \mathrm{F}\right)$. In the normal process of burning wood, unlimited air allows the wood to convert to 
gases and burn down to a small ash residue. In the process of carbonization or pyrolization, the limited air causes the wood to decompose chemically into charcoal. Charcoal has always been a preferred source of heat for smelting because it burns at a higher temperature than wood (twice the heat of seasoned wood) and more evenly and consistently than wood. Carbonization removes moisture and impurities, leaving a low ash content and low amount of trace elements such as sulfur and phosphorous. This means that the carbonization process produces a "clean" heat that enhances the quality and malleability of the iron smelter's output. The heat produced by charcoal is sufficiently intense to reduce iron oxide into pig iron, a process that requires a temperature of $1425^{\circ} \mathrm{C}$ to $1650^{\circ} \mathrm{C}\left(2600^{\circ} \mathrm{F}\right.$ to $\left.3000^{\circ} \mathrm{F}\right)$. Compared to wood, charcoal is much easier to transport and store. It is one-third of the weight and one-half of the volume of wood. Charcoal-burners produced the ideal fuel for the smelting process (Straka, 2017).

In 1850 between 150 and 200 bushels of charcoal were needed to smelt a ton of pig iron and by 1900 increased efficiency reduced the need to 80 to $100 \mathrm{bu}-$ shels (Straka \& Ramer, 2010). The Ironton Furnace, for example, between late 1882 and early 1883 , consumed about 88 bushels of charcoal per gross ton of pig iron produced (Birkinbine, 1883a). The charcoal iron industry created a tremendous demand for charcoal fuel.

The simplest method for charcoal production was the charcoal pit or meiler. The term "pit" was a misnomer, as the pit was constructed entirely above ground. Woodchoppers cut small trees into four-foot sections that could be used to form a multi-tier woodpile on a "hearth," a hard, level, and cleared ground area, about nine to twelve meters ( 30 to 40 feet) in diameter. The wood was tightly packed to form a mound shape and then covered with a thin layer of leaves and dirt, forming an airtight cover. The center of the pit contained a small triangular "chimney" constructed out of small branches, allowing ignition of the woodpile using hot coals from the collier's cooking fire. The chimney was then sealed, creating a "dead fire," one that was almost free of air. Vent holes at the base of the pit allowed more air when additional heat was needed. The collier carefully monitored the pit for a week to ten days until it charred entirely. Then the pit was totally sealed and allowed to cool for a week or so. Then the charcoal was ready for a trip to the furnace site (Kemper, 1941).

In the last quarter of the nineteenth century charcoal production by the pit method lost favor to kiln production. Stone, brick, or a combination of two were used to construct charcoal kilns that allowed for more efficient charcoal production and better control of the charcoal burning process. These were located near the iron furnaces or along the railroads that led to the furnaces. Charcoal pits generally held from 10 to 50 cords, with the average being 25 to 35 cords. Kilns can be divided into four designs: square or rectangular that held from 60 to 100 cords, round that held about 50 cords, conical that held from 15 to 40 cords, and bee-hive shaped kilns that held from 20 to 50 cords (Birkinbine, 1881). Charcoal 
kilns had an opening (door) at the bottom and an opening at or near the top for loading and unloading, plus vents at the bottom to control air flow (Kemper, 1941).

The charcoal kiln has four advantages: first, a kiln can be operated year-round, reducing the cost and risk of stockpiling charcoal; second, the charcoal is always fresh, clean, and free from dirt; third, kilns produce increased yields; and fourth, the kilns can be located where they are easy to tend and watch, producing more uniform charcoal. This method has three disadvantages: first, the kiln is expensive to construct; second, it is likely more expensive to haul wood to the kiln, but they may be offset by the construction costs of each pit; and third, there is an expense and risk in carrying the necessary supply inventory of cut wood to keep the kilns burning (Birkinbine, 1881). While the kilns were expensive to construct, they had cheaper operating costs with greater yields of better-quality charcoal. The main advantage of the pits was mobility. Only large transportation costs involved in getting the wood to the kilns would give the advantage to charcoal pits (Egleston, 1881).

The iron furnace at Ironton in Sauk County provides a good example of charcoal production. Pioneers found the area around what would become Ironton to be a hilly, timbered country, with much hardwood (oaks, hickory, basswood, and butternut, the kind that made the best charcoal). There was no market for this timber, and it was an impediment to farming. The furnace in Ironton created a market and soon woodchoppers were busy felling trees and cutting them into 1.2-meter (four foot) lengths for charcoal burning (Krug, 1929). The pay was 45 or 50 cents per cord, usually paid at the store (Charcoal Burning, 1917).

A local newspaper article on charcoal burning noted that the industry contributed much to opening up Sauk County to settlement and included a sketch of the charcoal burning in process (Figure 1 is the illustration described in the article). The sketch was by Lorell D. Ingram, a boyhood resident of the village who was very

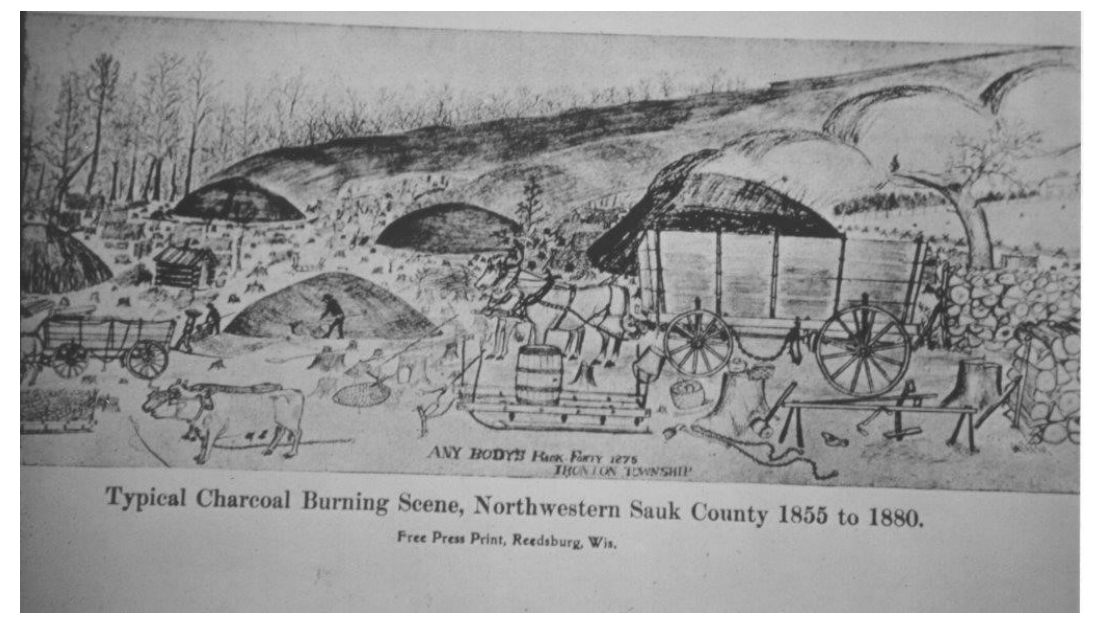

Figure 1. Lowell D. Ingram sketch of charcoal burning activities around Ironton, Wisconsin (Charcoal Burning, 1917; Reedsburg [Wisconsin] Public Library). 
knowledgeable about the iron furnace and charcoal burning. It was very "true to the actual fact" and illustrated the various stages of burning charcoal, as well as the surroundings and related activities. Note the many charcoal pits, wagons, sled, wood piles, cabin, and cleared land. In its later years, the furnace company paid six cents per bushel for charcoal delivered to their coal shed at the furnace. A cord of wood could be expected to yield about 30 bushels of charcoal when produced from local woodlands, providing the "princely sum of one dollar and eighty cents for the wood, timber burning and delivering." This was sufficient for the farmer reasonably close to the furnace to consider charcoal burning to be a "boon to theirbusiness and many hundreds of acres and many farms were thus opened to settlement years before it could have otherwise been done" (Charcoal Burning, 1917).

The furnace at Ironton began to operate kilns by the 1880s. These kilns (probably resembling the one in Figure 2) were described by an industry leader who visited the furnace in 1883 . They were "two 60-cord conical kilns, constructed of stone and brick." The kilns could be filled with wood in two to three days, then would be fired for eight days, and allowed to cool for a week. After cooling, it would take two days to empty the kilns. A cord of wood yielded 40 cords of charcoal, "free of brands and braize." Even with the kilns, the bulk of charcoal was reported to come from local charcoal pits, some on company property and some on other lands. The charcoal was hauled to the furnace in wagons, holding about 100 bushels each, usually drawn by two horses or a yoke of oxen. The average yield of a charcoal pit was reported to be $33^{1} / 3$ bushels per cord. The principal wood used was oak. The Iron Mountain Furnace Company also owned 1214 hectares (3000 acres) of woodlands, 567 hectares (1400 acres) of farmland, a gristmill, sawmill, store, barns, tenements, and many of the town lots in Ironton (Birkinbine, 1883b).

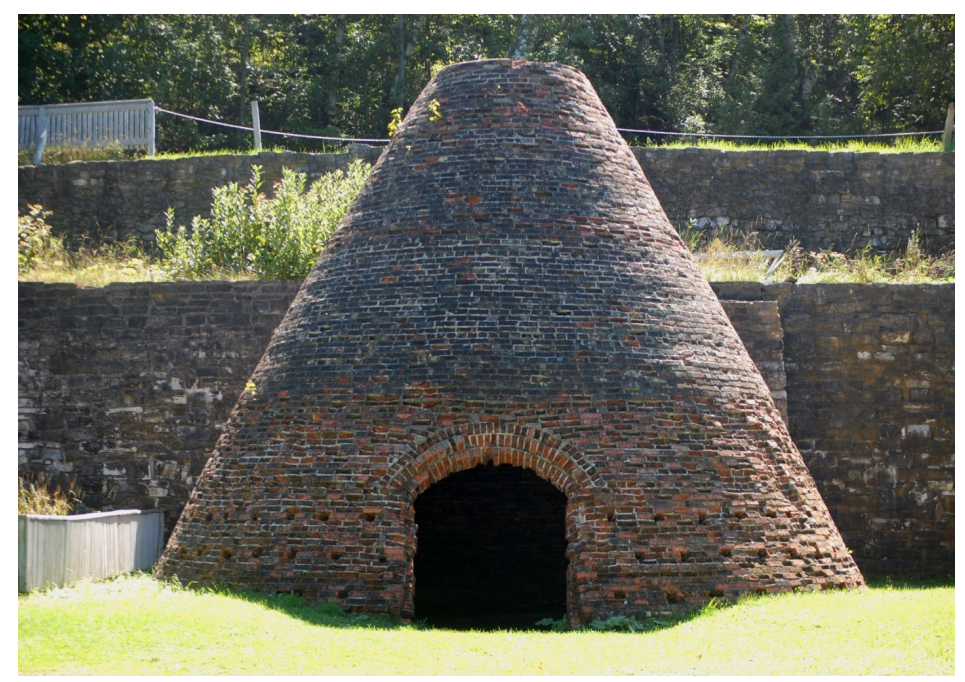

Figure 2. Charcoal kilns no longer exist in Wisconsin. This is a reconstructed conical kiln located at Fayette Historic State Park in Michigan's upper Peninsula (Legends of America). 
Ironton was actually a relatively small operation. But once the kilns were located at the furnace it became a smoky iron center. The MilwaukeeJournal described it as, "once Gary of the North Woods" (Walters, 1924). Today, the area where the kilns were located is an agricultural field (M. Cummings, personal communication, November 13, 2013). A 1917 newspaper article laments about the passing of the charcoal industry in Sauk County: "The business of burning charcoal is dead. It has gone with other relics of pioneer days, the beaver and buffalo, the wild turkey and the pigeon" (Charcoal Burning, 1917).

\section{Charcoal Burners, Teamsters, and Woodchoppers}

The charcoal production process is best illustrated with the requirements of burning a charcoal pit. Some locations like Ironton or Dodge County got most or all of their charcoal from pits, and furnaces bought charcoal from farmers who mad in pits (Martin, 1913). Early iron furnaces in Dodge County were noted as being surrounded by numerous charcoal pits (Frederick, 1993). A charcoal kiln essentially operated in a similar manner to a charcoal pit, the difference being that the kiln has a permanent covering of brick or stone and the pit had a temporary covering of earth.

To construct and operate a charcoal pit, first, the wood must come from somewhere. That is the province of the woodchoppers. They were the least skilled of the charcoal burning labor force, but by far the greatest in number. Typically, one-half or more of a furnace's employees would be woodchoppers (Walker, 2000). The furnace at Ironton produced the most detailed record of charcoal burning using pits in the state, including a sketch showing the lay-out of the entire process (Charcoal Burning, 1917). Charcoal production was considered one of the most important industries in Ironton, providing much of the village's employment. The furnace owned about 2428 hectares (6000 acres) near the Furnace that provided the wood (Western Historical Company, 1880b).

The position of woodchopper was a beginning level job, but it provided the opportunity for advancement (Bohn, 1944; Cole, 1918). Some immigrants simply used the iron furnace to recoup some capital from recently acquired land intended for agricultural production. To improve the land, cordwood would be cut from the standing timber (Figure 3), using it to burn charcoal, and delivering it to the Ironton furnace at a price of about $\$ 1.75$ a cord (Cole, 1918; Kury, 1993).

Woodchoppers had to master a basic skill of cutting all cordwood bolts to the same length, as they would form the (typically) three tiers within the charcoal pit. The bolts were cut in two sizes: billets which were roughly ten to 17 centimeters (four to seven inches) in diameter (usually cut from the tree trunk) and lapwood which was roughly four to ten centimeters (one and one-half to four inches) in diameter (usually cut from the branches). When a tier was created, lapwood could be used to fill in the open spaces within the pile making it as airtight as possible. One end of each billet and lapwood was cut on a bias so that the wood would lean inward to form the mound shape with a slanted side to retain the dirt that would later seal the pit (Kemper, 1941). Figure 4 shows the 


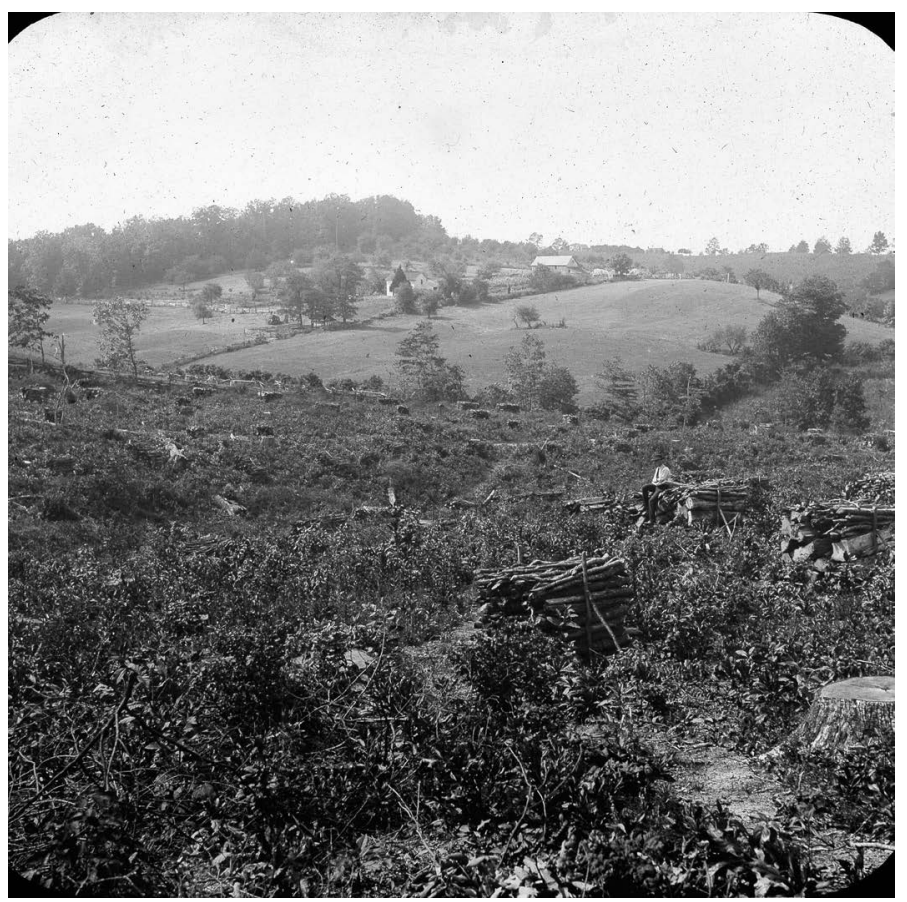

Figure 3. Woodchoppers cleared much forest land, stacking the cordwood in stacks that could be easily measured (Ohio Agricultural Experiment Station).

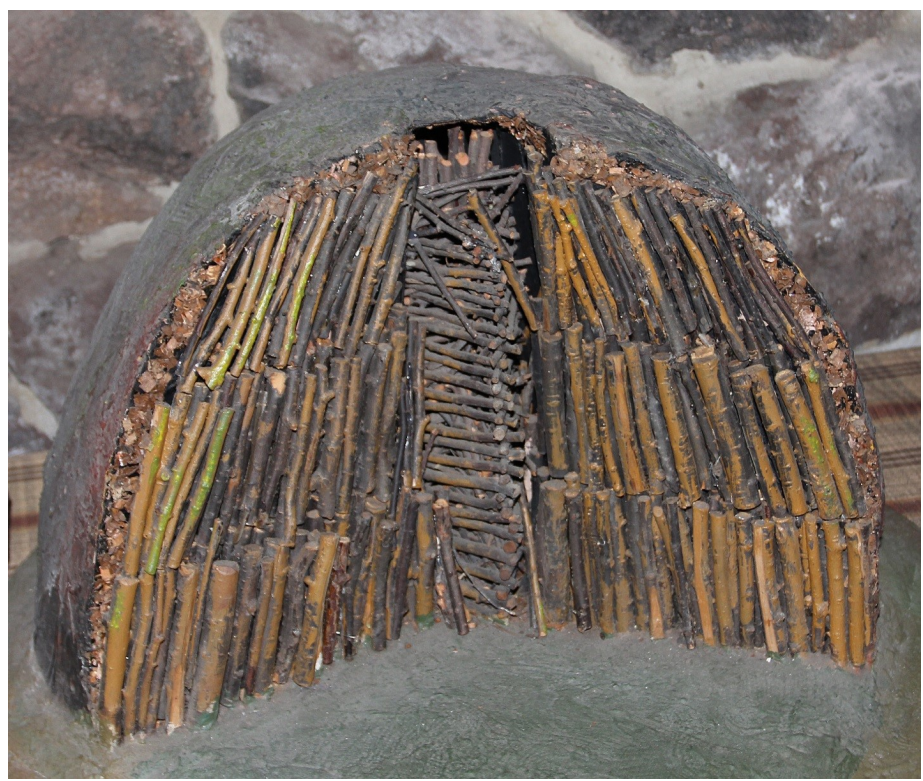

Figure 4. Structure of a charcoal pit, notice the triangular chimney in the middle, the tiers of wood, the leaves covering the wood, and the earthen covering (Photo by Doug Page).

structure of a charcoal pit and Figure 5 shows an actual charcoal pit with a charcoal burner on top. Notice in Figure 1, the "Typical Charcoal Burning Scene" by Ingham, that there are the many charcoal pit mounds with that slanted side.

The harvest had to be placed into neat piles so that it could be measured for payment, called "ranking" the wood. Two cords per day might be cut. A dishonest woodchopper might try to deceive the measurer by piling wood over stumps 


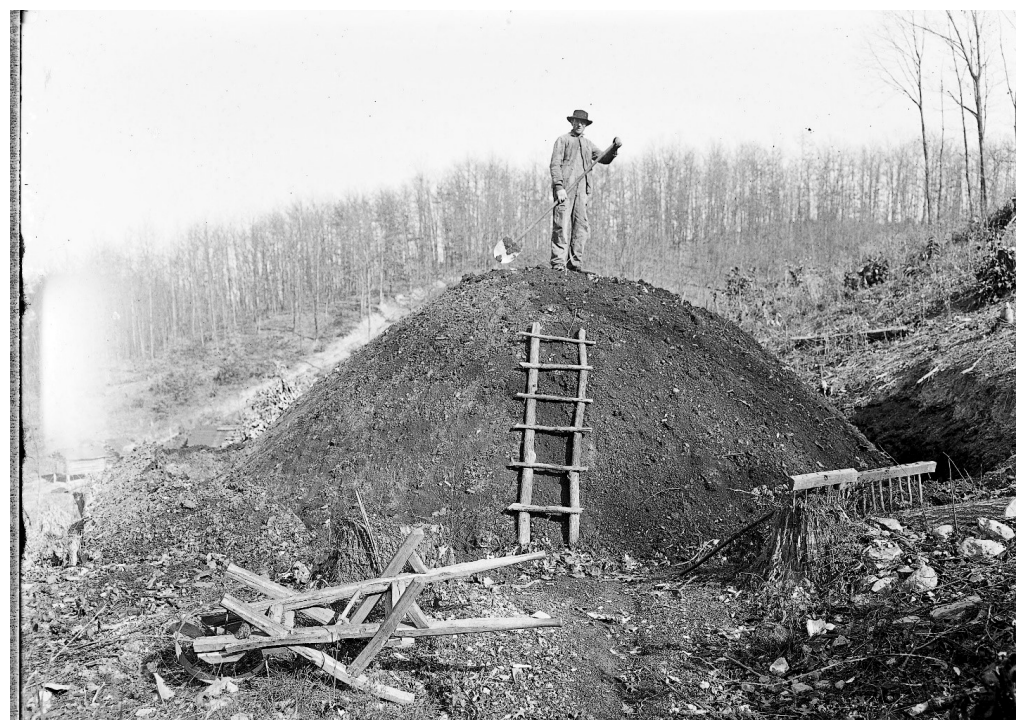

Figure 5. Charcoal burner atop a charcoal pit, covered and ready to burn (Ohio Agricultural Experiment Station).

or rocks, piling roughly, or cutting short billets. If caught, the woodcutter would be "docked" for the deception (Kemper, 1941).

If he was working far from home, the collier might build a shelter in the woods (Figure 6). Woodchoppers were often also employed as a woodhauler, the person who moved the wood from the ranks to the charcoal pit, using a long wooden sled or jumper (some were as long as ten feet) pulled by a yoke of cattle or oxen (Figure 7). The jumper could hold half a cord. Charcoal pits were usually located at a lower elevation than the wood source so that the jumper would be moving downhill (Charcoal Burning, 1917; Kemper, 1941; Walker, 2000). Note in Figure 1 that most aspects of charcoal making are displayed and that present are ranked wood and a jumper being used to haul a barrel.

The wood was hauled to a hearth, an area which served as the base of the charcoal pit. The wood hauler was responsible for creating the tiered wood pile that would form the charcoal pit. He would first create a small rectangular chimney at the center of the hearth using lapwood. Around the chimney billet leaned inward so that the side of the pit had enough slope to hold an earthen covering. Lapwood was used to fill any spaces left by the billets. Billets were used to construct the first two tiers and then the third tier would be built up another 0.9 to 1.2 meters (three or four feet) using lapwood horizontally radiating from the center (Gordon, 1996). Notice in Figure 1 that the bottom tier is barely visible in one of the pits.

Each tier of the pit was tighter than the previous one so that a mound-shape and rounded top were formed. The last step in constructing the wood pile was lapping-off or using the remaining lapwood to fill in any open spaces. Once "lapping off" was complete the pit was considered "set," and a crude ladder was constructed so that the collier and his helpers could reach top of the wood pile (Figure 5). The top of the chimney would then be filled with kindling and 


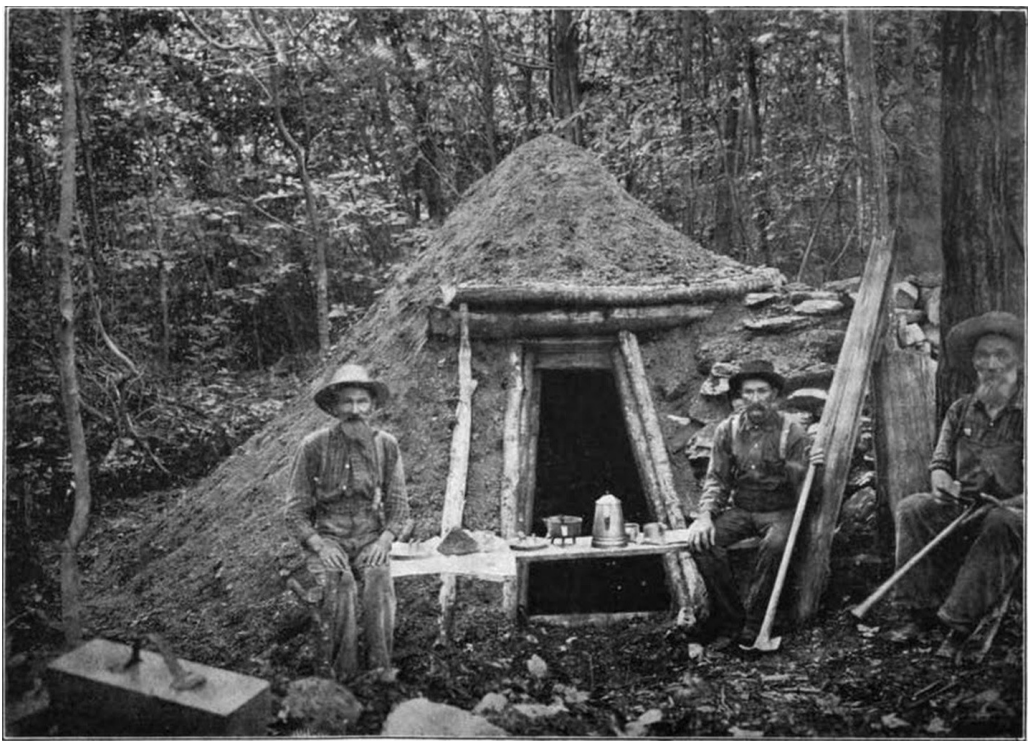

Figure 6. Charcoal burners had to live near the charcoal pits to provide constant supervision; these teepee type shelters were a common structure for charcoal burners and reported to be used in Ironton (Rothrock, 1907).

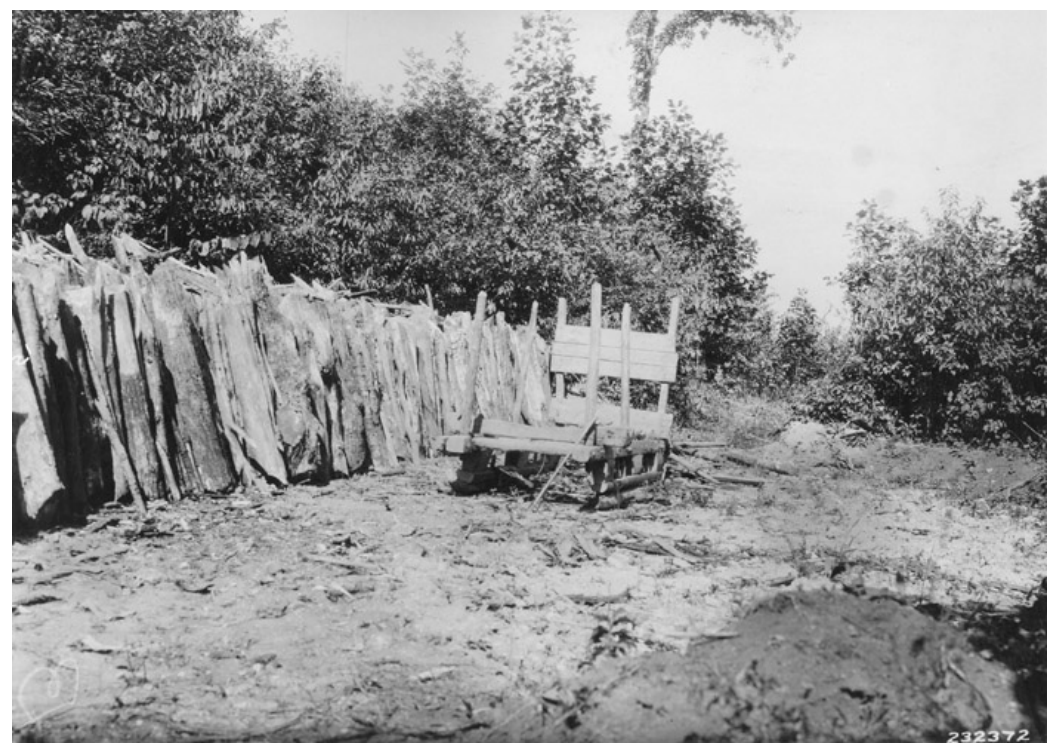

Figure 7. Wood has been transported to the hearth and stacked, ready to be placed into the charcoal pit. A sled used to transport the wood is next to the stacked wood (Forest History Society).

covered with several billets and lapwood. The pit was now ready for "leafing and dusting" (Charcoal Burning, 1917). The collier and his helpers ended up dirty and even blackened from all the work, and a local term for them was "raggies" (Weber, 1971).

Working his way up, a woodchopper might serve as a collier's helper, at least at first, as it would take some time to acquire collier skills. He would have carefully placed a layer of leaves a few inches thick over the wood and then dust (soil) over that to uniformly seal the pit. The pit was then ready for firing by 
opening the top and inserting hot coals from the collier's cooking fire. Once the pit was ignited, the top opening was sealed, and the collier was required to provide 24-hour supervision of the burning and its proper progression. Heat or shifting within the pit could produce cracks and let in too much air, resulting in a pile of ashes if not caught. The collier would need an extra bushel of dust for every cord burned for "dressing" the pit as it burned (Kemper, 1941). Notice in Figure 1 burning charcoal pits are being tended.

Charcoal burning required a "dead fire," one receiving a very small amount of oxygen, as a burning fire would produce that ash. Vent holes were made at the base if more heat was needed. The original ignition was called "firing the pit" and using the vents to increase draft and heat was called "giving er' fire." A 100 -cord pit might take from three weeks to a month to burn through. Then it would be sealed and allowed to cool for a week to ten days. If neglect led to a charge of wood burning to ash, the furnace charged the collier for the lost wood. Opening a pit required skill. Unless the pit was completely cold the pit could reignite. Usually the charcoal was removed in layers or portions as the pit cooled (Kemper, 1941).

"Jumping the pit" was a dangerous aspect of the job. The collier needed to keep a watch for soft spots or "mulls" on the top of the pit. He would gently walk across the top looking for mulls. Finding one, he would jump up and down on the harder parts of the pit to fill in the spaces created by the mull. This could prove fatal or result in serious burns if the collier was not careful and broke through the covering (Kemper, 1941).

Some immigrants arrived with collier skills. Some used their skills as a charcoal burner for until they saved enough to begin farming (Cole, 1918). A collier had social status in the ironwork community, as he was highly skilled and the quality of his charcoal affected the quality of the furnace output. The ironmaster needed a strong, compact, and heavy charcoal, and skill was required to produce that. A good collier also could produce higher yields of charcoal from a bushel of wood, requiring great skill in judging progression of the "dead fire" through the pit based on the quantity and color of the smoke produced and heat generated from the pit. Controlling limited airflow via the vents at the bottom of the pit was the key skill. That meant being able to judge when the burn was complete and later when the charcoal was ready to be "raked" from the pile. Should the charcoal ignite and burn, the collier did not get paid and could be liable for the wood used in production (Walker, 2000).

The collier's liability even went as far as the transportation of charcoal to the furnace in charcoal wagons. Notice the charcoal wagons in Figure 1 and Figure 8. One thing special about a charcoal wagon was that the planks that made up the floor of the wagon could be slid out from the back of the wagon dropping the charcoal onto the ground. If the collier sent a load of charcoal to the furnace which had not been properly cooled and it caught back on fire during the trip, both the wagon and the charcoal could be lost due to fire. The teamster would pull the floorboards of the wagon if that occurred and drop the charcoal onto the 


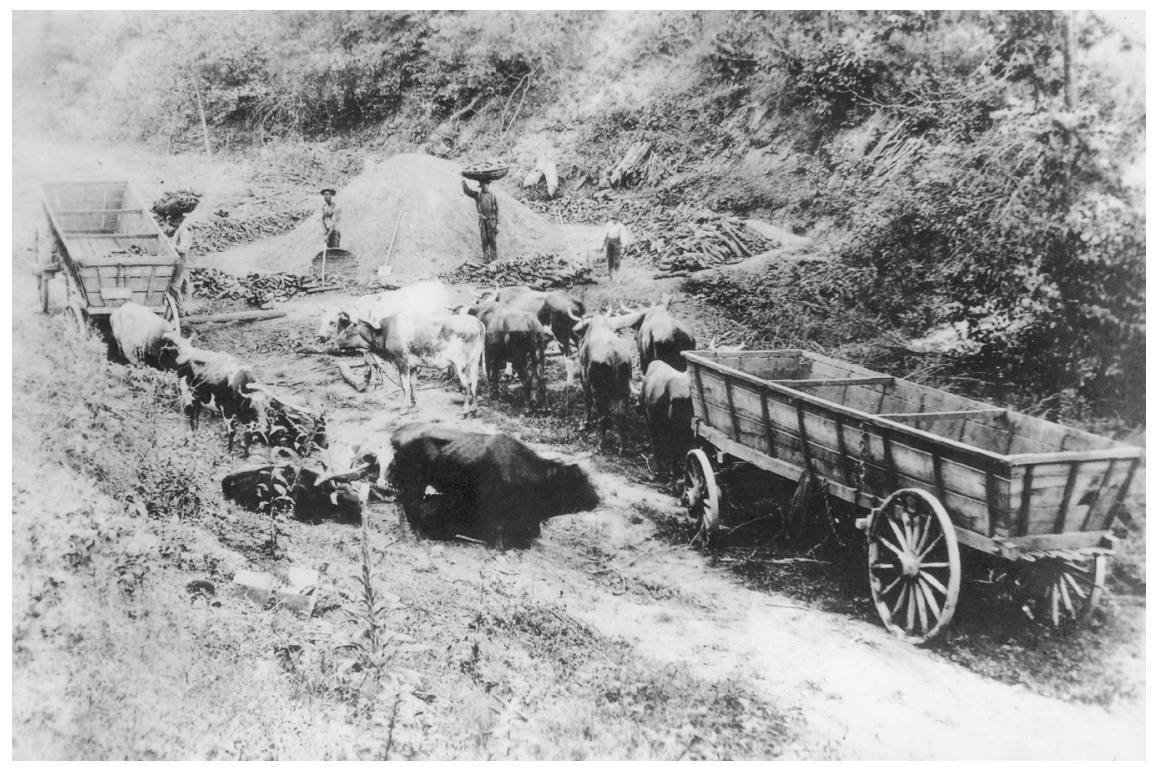

Figure 8. Teamsters with charcoal wagons transported the charcoal from the pits to the furnace (Ohio History Connection).

road, saving the wagon and perhaps some of the charcoal. Any loss from an in-transit charcoal fire would be the responsibility of the collier. Those floorboards did allow for easy unloading of charcoal at the charcoal house (Walker, 2000). A charcoal house was essentially a large barn or shed where charcoal could be stored before use. Obviously, it was located near the furnace and essential to keep he charcoal dry (Bohn, 1944).

The collier would supervise several charcoal pits located close to each other and, since that supervision was required to be constant, he might build a temporary shelter near the pits. The Ingham sketch shows a cabin such as those which might have been used. But the traditional collier shelter was a collier's hut that resembled an earth-covered teepee. Some of the charcoal huts at Ironton were described as "built in the shape of an Indian teepee, circular in form and covered with leaves and dirt (Charcoal Burning, 1917). The Ironton Furnace could not have operated without skilled colliers willing to live for weeks in those huts.

All of the masonry charcoal kilns operated the same way as the pits, minus the earthen covering. Instead of watching a group of charcoal pits, a collier would watch a set of charcoal kilns. The type of charcoal kiln often located along the railroads is shown in Figure 9. The difference was that the collier managing the kilns did not need to watch for cracks in the covering. For example, a set of nine large kilns located on a railroad spur were located just west of Withee near the Black River. They were massive circular masonry structures built with three layers of brick with ten-inch steel bands around the outside every 1.2 meters (four feet) to prevent the kilns from bursting due to the tremendous heat. The kilns were loaded from the top via 1.2-meter (four-foot) steel doors with a trestle for workers to carry the cordwood (Kowalski, 2001).

The collier would ignite the kiln from the bottom where another door was lo- 
cated, and, very similar to the operation of a charcoal pit, he controlled the burn with vent holes at the bottom, the size of bricks so that he could open and close the vents as necessary. The charcoal was loaded into special railroad cars built low enough so that men could easily dump in charcoal without having to climb into the cars. The content of one kiln could fill two railroad cars (Kowalski, 2001). The Ashland Iron and Steel Company had a massive set of kilns located near the furnace (Figure 10).

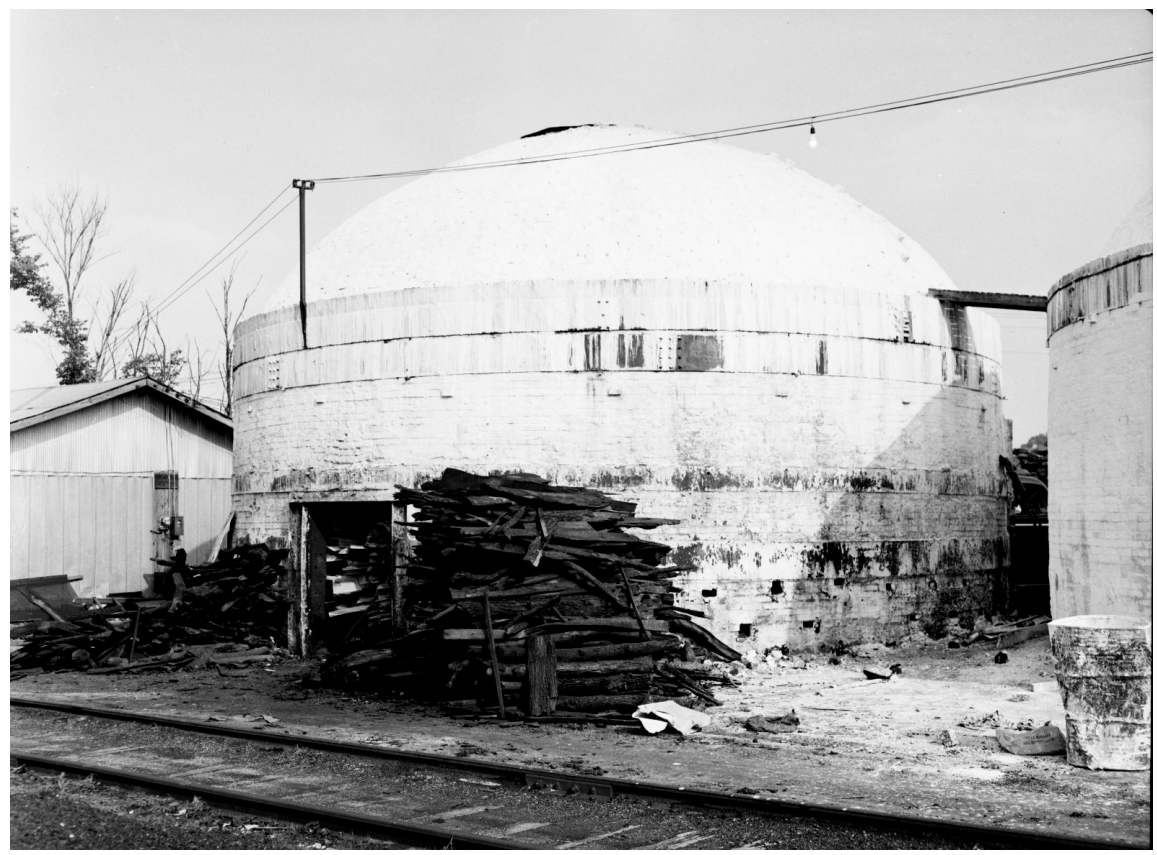

Figure 9. A circular charcoal kiln with a beehive type top, similar to the kilns along Wisconsin's rail lines. Charred slabwood piled in front of the kiln (Credit: Ohio Agricultural Experiment Station).

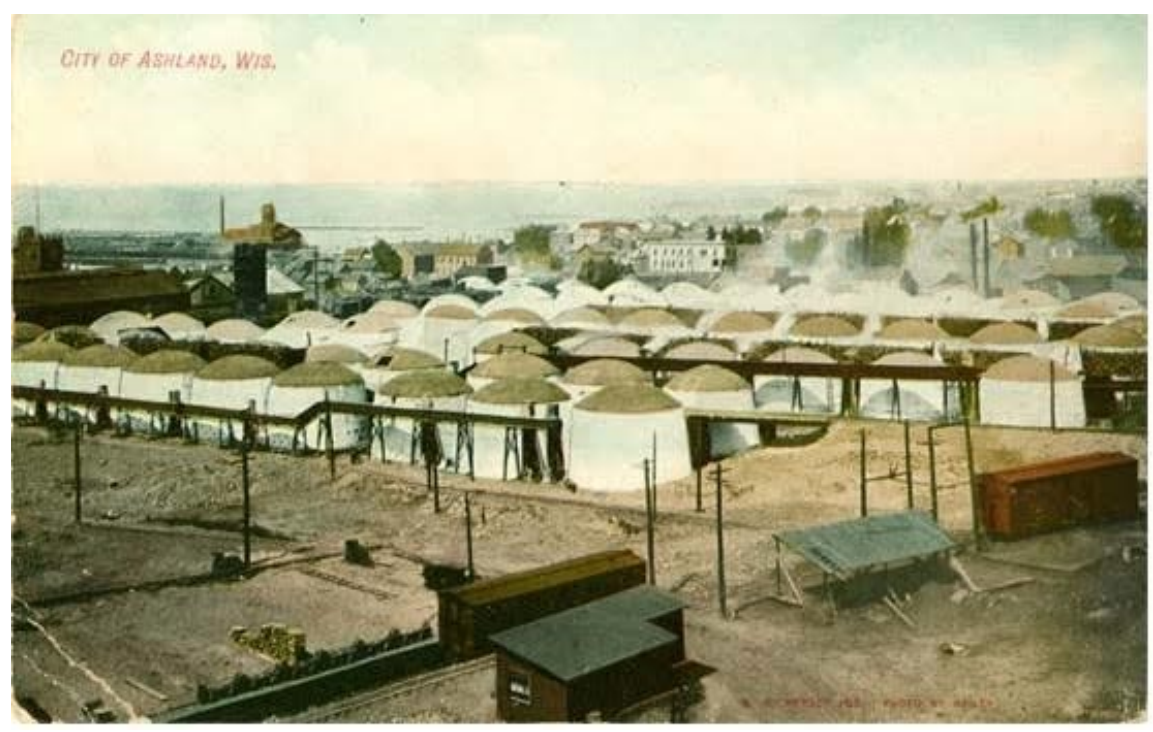

Figure 10. Charcoal kilns at Ashland Iron and Steel, largest charcoal iron furnace in world (Ashland [Wisconsin] Historical Society Museum). 


\section{Forest Conservation}

In other states forest conservation was an issue. Iron furnaces could not operate without a long-term supply of fuel. Some of the earliest forest conservation and management were developed around these furnaces as trees were cut and regrown in cycles, providing a permanent supply of charcoal. Surprisingly, the charcoal iron industry was one of the early efforts to practice sustainable forestry (Birkinbine, 1880). That did not stop the popular press from decrying the industry as a cause of forest devastation, as shown in a political cartoon from 1884 in Figure 11 (Keppler, 1884).

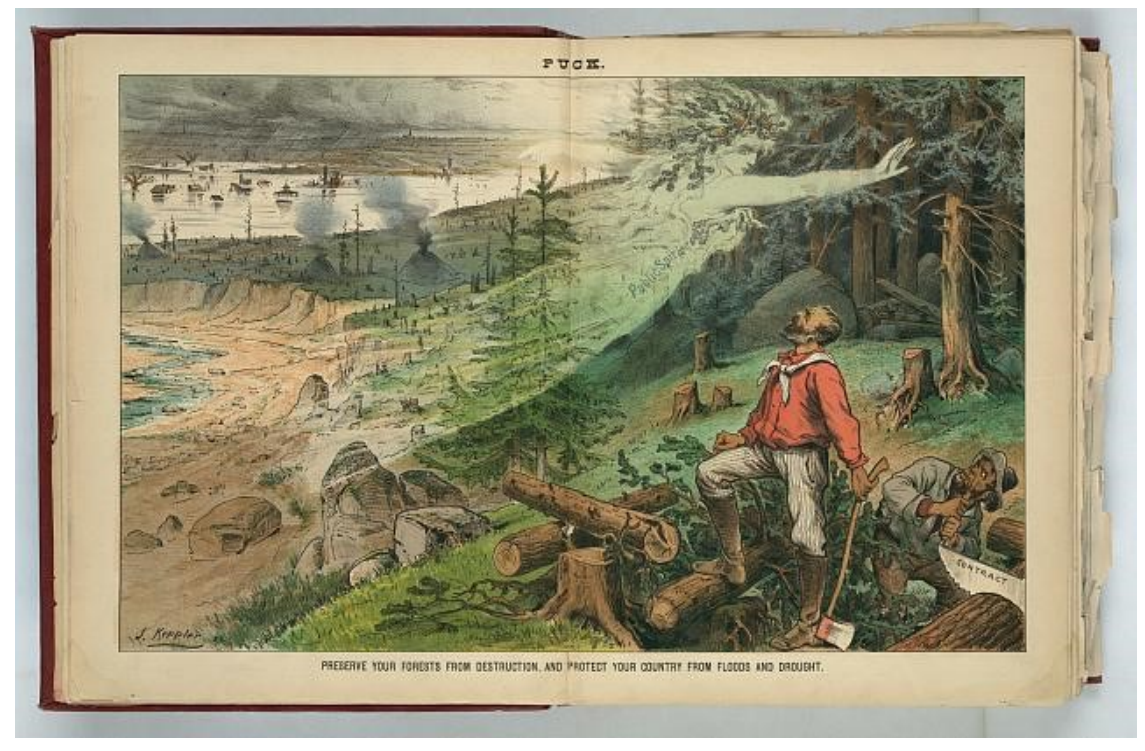

Figure 11. Political cartoon decrying the need for forest preservation, early in the conservation movement, and focusing on charcoal burning. Note the charcoal pits burning near the water and the forest destruction, resulting in floods, drought, and erosion (Library of Congress).

In Wisconsin, forest sustainability was not often an issue. Forests were considered a hindrance to converting land into agricultural production. But the demand for charcoal was so great that land clearing extended beyond potential farmland. In Ironton it was reported that charcoal demand was the "cause of much larger clearings having been made than otherwise would have happened" (Western Historical Company, 1880b). County histories that mention charcoal production consistently praise it for providing much needed revenue to struggling farmers by providing a market for trees stripped from the land to create fields (Bohn, 1944; Satterlee, Tift \& Marsh, 1890). In Brown County, for example, all marketable timber was harvested by 1875 , leaving "refuse' timber that cost about $\$ 8$ per hectare ( $\$ 20$ per acre) to remove. New iron furnaces then "called for so much charcoal to smelt the iron ore that all the wood in the county was soon marketed at profitable prices and the county rapidly became an agricultural county and is now [1913] one of the best in the state" (Martin, 1913).

A major reason that the Ironton Furnace shut down in the mid-1890s was the 
lack of wood and increasing charcoal costs (Palmer, 1910). Likewise, furnaces in Brown County, Appleton and Fond du Lac closed for the same reasons (Straka \& Gueller, 2020). Much of the iron smelting industry in Wisconsin was dependent upon a limited resource-the state's forests; they helped create the opportunity for an important industry, but, as they became depleted, iron smelters became unprofitable. The iron smelting industry in Wisconsin has a colorful history that is also part of the state's forest conservation history.

\section{Conflicts of Interest}

The authors declare no conflicts of interest regarding the publication of this article.

\section{References}

American Iron and Steel Association (1890, 1892, 1896, 1904). Directory to the Iron and Steel Works of the United States. Philadelphia, PA: American Iron and Steel Association. https://catalog.hathitrust.org/Record/007088774

Birkinbine, J. (1880). The Denudation of Our Forests. Journal of the United States Association of Charcoal Iron Workers, 1, 33-39.

http://quod.lib.umich.edu/m/moajrnl/ahj4772.0001.001/56

Birkinbine, J. (1881). Our Fuel. Journal of the United States Association of Charcoal Iron Workers, 2, 66-79.

http://quod.lib.umich.edu/m/moajrnl/ahj4772.0001.002/76

Birkinbine, J. (1883a). Notable Blast-Furnace Records. Journal of the United States Association of Charcoal Iron Workers, 4, 21-24.

http://quod.lib.umich.edu/m/moajrnl/ahj4772.0001.004/44

Birkinbine, J. (1883b). Charcoal Industries in the Northwest. Journal of the United States Association of Charcoal Iron Workers, 4, 168-175.

https://quod.lib.umich.edu/m/moajrnl/ahj4772.0001.004/195:42?.rgn=full+text;view=i mage

Birkinbine, J. (1890). American Pig Iron Production in 1889. Journal of the United States Association of Charcoal Iron Workers, 8, 341-347.

https://quod.lib.umich.edu/m/moajrnl/ahj4772.0001.008/365:81?rgn=full+text;view=i $\underline{\text { mage }}$

Bohn, B. C. (1944) The Village of Ironton. Wisconsin Magazine of History, 27, 310-320.

Charcoal Burning (1917). Ironton, WI: Reedsburg Free Press.

https://www.wisconsinhistory.org/Records/Newspaper/BA6938

Charcoal Industry (1879). Oshkosh Daily Northwestern.

Cole, H. E. (1918). A Standard History of Sauk County, Wisconsin. Chicago, IL and New York, NY: The Lewis Publishing Company.

https://content.wisconsinhistory.org/digital/collection/wch/id/49544/rec/4

Coman, K. (1918). The Industrial History of the United States. New York, NY: The Macmillan Company. https://catalog.hathitrust.org/Record/100485884

Current, R. N. (1977). Wisconsin: A Bicentennial History. New York: W. W. Norton \& Company.

Curtiss-Wedge, F. (1918). History of Clark County, Wisconsin. Chicago, IL and Winona, MN: H. C. Cooper, Jr. \& Company. 
https://content.wisconsinhistory.org/digital/collection/wch/id/19965/rec/1

Dodd, J. M. (1944). Ashland Then and Now. Wisconsin Magazine of History, 28, 188-196.

Egleston, T. (1881). The Manufacture of Charcoal in Kilns. Journal of the United States Association of Charcoal Iron Workers, 2, 55-63.

http://quod.lib.umich.edu/m/moajrnl/ahj4772.0001.002/64

Fell Jr., J. E. (2009). Ore to Metal: The Rocky Mountain Smelting Industry. Boulder, CO: University Press of Colorado.

Francis, G. H. (1882). The Fond du Lac Furnace. Journal of the United States Association of Charcoal Iron Workers, 3, 146.

http://quod.lib.umich.edu/m/moajrnl/ahj4772.0001.003/185

Frederick, G. G. (1993). When Iron Was King in Dodge County, Wisconsin, 1845-1928. Mayville, WI: Mayville Historical Society.

Gordon, R. B. (1996). American Iron: 1607-1900. Baltimore, MD: The Johns Hopkins University Press.

Hough, F. B. (1882). Report on Forestry Submitted to Congress by the Commissioner of Agriculture. Washington, DC: Government Printing Office.

https://catalog.hathitrust.org/Record/100421436

Irving, R. D. (1883). Iron Ores. In T. C. Chamberlin (Ed.), Geology of Wisconsin: Survey of 1873-1879, Vol. I (pp. 613-614). Madison, WI: David Atwood. https://pubs.er.usgs.gov/publication/70039181

Ise, J. (1920). The United States Forest Policy. New Haven, CT: Yale University Press. https://catalog.hathitrust.org/Record/001508769

Janik, E. (2010). A Short History of Wisconsin. Madison, WI: Wisconsin Historical Society Press.

Jones, G. O., \& McVean, N. S. (1923). History of Wood County, Wisconsin. Minneapolis, $\mathrm{MN}$ and Winona, MN: H. C. Cooper, Jr. \& Company.

Kemper III., J. (1941). American Charcoal Making in the Era of the Cold-Blast Furnace (Popular Studies Series, History No. 14). Washington DC: National Park Service. https://www.nps.gov/parkhistory/online_books/popular/14/ps14-1.htm

Keppler, J. F. (1884). Preserve Your forests from Destruction, and Protect Your Country from Floods and Drought. Puck, 14, 296-297.

http://www.loc.gov/pictures/item/2012645164/

Kowalski, M. (2001). Black River Coke Kilns. In Centennial Book Committee (Ed.), Withee Memories: From Logging to Super Highways (pp. 99). Withee, WI: O-W Enterprise.

Krug, M. E. (1929). History of Reedsburg and the Upper Baraboo Valley. Madison, WI: Democrat Printing Company.

Kury, T. W. (1993). Labor and the Charcoal Iron Industry: The New Jersey-New York Experience. Material Culture, 25, 19-33.

Lesley, P. (1857). Bulletin of the American Iron Works Association. Philadelphia: American Iron Works Association.

Martin, D. B. (1913). History of Brown County, Wisconsin: Past and Present. Vol. I, Chicago, IL: The S. J. Clarke Publishing Company. https://catalog.hathitrust.org/Record/008652971

Merk, F. (1916). Economic History of Wisconsin during the Civil War Decade. Vol. I, Madison, WI: State Historical Society of Wisconsin. 
https://catalog.hathitrust.org/Record/006271810

Palmer, L. H. (1910). Early Industries in Sauk County: Papers Read before the Sauk County Historical Society Meetings. Baraboo, WI: Sauk County Historical Society. https://saukcountyhistory.org/early-industries-in-sauk-county

Raymond, R. W. (1875). Statistics of Mines and Mining in the States and Territories West of the Rocky Mountains. Washington DC: Government Printing Office. https://catalog.hathitrust.org/Record/007457283

Rothrock, J. T. (1907). The Collier's Cabin. In Report of the Pennsylvania Department of Forestry for the Years 1905 and 1906. Harrisburg, PA: Harrisburg Printing Company.

Ryan, T. H. (1911). History of Outagamie County, Wisconsin. Chicago, IL: Goodspeed Historical Association. https://content.wisconsinhistory.org/digital/collection/wch/id/39244/rec/1

Satterlee, Tift \& Marsh (Comps.). (1890). Clark County, the Garden of Wisconsin. Neillsville, WI: Satterlee \& Tift.

https://content.wisconsinhistory.org/digital/collection/wch/id/19964

Schallenberg, R. H. (1975). Evolution, Adaptation and Survival: The Very Slow Death of the American Charcoal Iron Industry. Annals of Science, 32, 341-358. https://doi.org/10.1080/00033797500200331

Schallenberg, R. H., \& Ault, D. A. (1977). Raw Material Supply and Technological Change in the American Charcoal Iron Industry. Technology and Culture, 18, 436-466. https://doi.org/10.2307/3103901

Smith, J. S., \& Goc, M. J. (1987). Looking Backward Moving Forward, Ashland: The Garland City of the Inland Seas. Friendship, WI: New Past Press Inc.

Straka, T. J. (2014). Historic Charcoal Production in the US and Forest Depletion: Development of Production Parameters. Advances in Historical Studies, 3, 104-114. http://dx.doi.org/10.4236/ahs.2014.32010

Straka, T. J. (2017). Charcoal as a Fuel in the Ironmaking and Smelting Industries. Advances in Historical Studies, 6, 56-64. https://doi.org/10.4236/ahs.2017.61004

Straka, T. J., \& Gueller, L. A. (2020). Fuel for Northeast Wisconsin's Iron Smelting Industry: A History of Charcoal Kilns. Voyageur: Northeast Wisconsin's Historical Review, $36,32-41$.

Straka, T. J., \& Gueller, L. A. (n.d.). Charcoal Burning Industry in Clark County and Bordering Counties. https://wiclarkcountyhistory.org/7data/141/141141.htm

Straka, T. J., \& Ramer, W. C. (2010). History on the Road: Hopewell Furnace National Historical Site. Forest History Today, 16, 58-62. https://foresthistory.org/wp-content/uploads/2016/12/2010_History-on-Road.pdf

Swank, J. M. (1892). History of the Manufacture of Iron in All Ages, and Particularly in the United States from Colonial Times to 1891. Philadelphia, PA: American Iron and Steel Association. https://catalog.hathitrust.org/Record/007586566

Swank, J. M. (Ed.). (1873). The Iron Industries of Wisconsin. Bulletin of the American Iron and Steel Association, 7, 147.

Walker, J. E. (2000). Hopewell Furnace: The Dynamics of a Nineteenth-Century Iron-Making Community. Fort Washington, PA: Eastern National.

Walters, B. E. (1924). Ironton, Wis., Once Gary of the North Woods. https://www.wisconsinhistory.org/Records/Newspaper/BA6944

Weber, A. (1971). Charcoal to Burn. Wisconsin Trails, 12, 31-34.

Western Historical Company (1880a). The History of Fond du Lac, Wisconsin. Chicago, 
IL: Western Historical Company. https://catalog.hathitrust.org/Record/009604903

Western Historical Company (1880b). The History of Sauk County, Wisconsin. Chicago, IL: Western Historical Company. https://catalog.hathitrust.org/Record/009599269

Winn, D. L. (1989). History of Ironton. Ironton, WI: D.L. Winn. 